\title{
Brief Extensions of Curing and Presprouting Increased Plant Production from Bedded Sweetpotato
}

\author{
Melvin R. Hall ${ }^{1}$ \\ Department of Horticulture, University of Georgia Coastal Plain \\ Experiment Station, Tifton, GA 31793
}

Additional index words Ipomoea batatas, emergence, sprouts, plant harvests

Abstract. 'Georgia Jet' and 'Jewel' sweetpotato (Ipomoea batatas L.) roots were cured $(32 \pm \mathrm{C}$ IC, $85 \% \pm 5 \%$ relative humidity $(\mathrm{RH})]$ for 7 days immediately after harvest and then subjected to $0,4,8$, or 12 additional days of curing before storage $(16 \pm \mathrm{IC}$, $85 \% \pm 5 \%$ RI-I). Roots were presprouted $(32 \pm \mathrm{IC}, 85 \% \pm 5 \% \mathrm{RH})$ for $0,4,8$, or 12 days before bedding. Plant emergence of 'Georgia Jet' was accelerated with increasing duration of curing, but emergence of both cultivars was accelerated with increasing duration of short-interval presprouting. With increasing duration of extended curing, there was a nonlinear increase in the number of early and total 'Georgia Jet' plants. However, with increasing duration of presprouting, there was a linear increase in the number of early and total plants of both cultivars. Average weights of early and total 'Jewel' plants were higher than those of 'Georgia Jet' plants. Treatments did not influence deterioration of bedded roots or the number of sprouts remaining on roots of a cultivar after 9 weeks of plant harvest. However, 'Jewel' roots retained more sprouts than 'Georgia Jet' roots, possibly indicating greater capacity for continued production of plants from 'Jewel' than 'Georgia Jet' if additional plant harvests were conducted.

Sweetpotato roots should be cured $[32 \pm$ $1 \mathrm{C}, 85 \% \pm 5 \%$ relative humidity $(\mathrm{RH})]$ for $\approx 1$ week following harvest to promote healing of wounds; then roots should be stored $(16$ \& $\quad$ C, $75 \%$ to $80 \% \mathrm{RH})$ to maintain quality (Steinbauer and Kushman, 1971). Transplants are produced from roots taken from storage and placed in propagating beds. Presprouting for 3 weeks $(32 \pm 1 \mathrm{C}, 85 \%$ $\pm 5 \% \mathrm{RH})$ before bedding has been a standard method of increasing plant production for >30 years (Deonier and Kushman, 1960), but rising energy costs have made this practice expensive. Cultivars vary in plant production potential (Cordner et al., 1966) and in their response to cultural practices intended to improve plant production (Michael and Smith, 1952).

Propagation of transplants from bedded roots is a major expense in the commercial production of sweetpotatoes in the United States, and practices that reduce the time in-

Received for publication 9 Dec. 1991. Accepted for publication 10 June 1992. Use of trade names does not imply endorsement by the Georgia Agricultural Experiment Stations of the products named nor criticism of similar products not mentioned. This research was supported by state and Hatch Act funds allocated to the Georgia Agricultural Experiment Stations. The cost of publishing this paper was defrayed in part by the payment of page charges. Under postal regulations, this paper therefore must be hereby marked advertisement solely to indicate this fact.

'Associate Professor. terval from bedding until plant harvest or increase the total number of transplants can reduce this cost. Short-duration presprouting for 9 or 10 days increased the number of early and total plants produced and reduced the time intervals from bedding until emergence, emergence until first harvest, and from bedding until first harvest (Hall, 1987, 1990).

In storage facilities that lack refrigeration, early harvested roots may be subjected to temperatures well above 16C for several weeks, and these higher temperatures may prolong the exposure of these roots to curing conditions. However, storing roots under such conditions is not recommended because of excess sprouting, shrinkage, and shortened storage life (Steinbauer and Kushman, 1971).

Deonier and Kushman (1960) reported increased plant production from 'Porto Rico' roots cured for an average of 18 days rather than for $\approx 7$ days. However, in their study, curing was not as effective as similar durations of presprouting for increasing plant production. The controlled application of heat to extend curing for enhanced plant production from bedded roots has not been adapted as a commercial practice. The objective of this study was to determine if brief extensions of the prestorage curing period, either with or without brief presprouting immediately before bedding, would influence plant production from roots of two sweetpotato cultivars.

All combinations of four durations of extended curing and four durations of pre- 
Table 1. Number of days from bedding until emergence and early and total cumulative number of plants harvested from plots of 10 bedded 'Georgia Jet' and 'Jewel' sweetpotato roots as influenced by cultivar and extended curing.

\begin{tabular}{|c|c|c|c|c|c|c|}
\hline \multirow{3}{*}{$\begin{array}{l}\text { Extended } \\
\text { curing } \\
\text { (days) } \\
\end{array}$} & \multirow{2}{*}{\multicolumn{2}{|c|}{$\begin{array}{c}\text { Emergence } \\
\text { (days from bedding) } \\
\end{array}$}} & \multicolumn{4}{|c|}{ Cumulative no. plants } \\
\hline & & & \multicolumn{2}{|c|}{ Early } & \multicolumn{2}{|c|}{ Total } \\
\hline & Georgia Jet & Jewel & Georgia Jet & Jewel & Georgia Jet & Jewel \\
\hline $\begin{array}{l}0 \\
4 \\
8 \\
12\end{array}$ & $\begin{array}{l}17^{2} \\
16 \\
14 \\
12 \\
L^{* *}\end{array}$ & $\begin{array}{l}22^{* *} \\
19^{\text {NS }} \\
22^{* *} \\
17^{* *} \\
\text { NS }\end{array}$ & $\begin{array}{c}18 \\
26 \\
13 \\
28 \\
L^{*} Q^{* *}\end{array}$ & $\begin{array}{l}20^{\text {NS }} \\
16^{* *} \\
19^{\text {NS }} \\
16^{* *} \\
\text { NS }\end{array}$ & $\begin{array}{c}37 \\
40 \\
35 \\
49 \\
L^{*} Q^{* *} C^{* *}\end{array}$ & $\begin{array}{l}43^{*} \\
39^{\text {NS }} \\
43^{* *} \\
38^{* *} \\
\text { NS } \\
\end{array}$ \\
\hline
\end{tabular}

${ }^{2}$ Means do not average because of rounding and because analyses were conducted on transformed data and back-transformed means are presented.

ss, Comparisons within columns or rows nonsignificant or significant at $P=0.01$ or 0.05 , respectively. $\mathrm{L}=$ linear, $\mathrm{Q}=$ quadratic, $\mathrm{C}=$ cubic .

Table 2. Influence of presprouting on number of days from bedding to emergence and early and total cumulative number of plants harvested after nine consecutive plant harvests during a 13-week harvest period from plots of 10 bedded sweetpotato storage roots.

\begin{tabular}{lccc}
\hline \hline Presprouted & $\begin{array}{c}\text { Emergence } \\
\text { (days) }\end{array}$ & \multicolumn{2}{c}{$\begin{array}{c}\text { Cumulative } \\
\text { no. plants }\end{array}$} \\
\cline { 2 - 4 } bedding) & Early & Total \\
\hline 0 & $21^{z}$ & 15 & 38 \\
4 & 18 & 20 & 40 \\
8 & 15 & 20 & 41 \\
12 & 16 & 24 & 44 \\
Significance & $\mathrm{L}^{* *} \mathrm{Q}^{* *}$ & $\mathrm{~L}^{* *}$ & $\mathrm{~L}^{* *}$ \\
\hline
\end{tabular}

${ }^{2}$ Means within columns pooled across other main effects (cultivar and extended cure).

**Significant at $P=0.01$. $\mathrm{L}=$ linear, $\mathrm{Q}=$ quadratic.

sprouting were imposed on 'Georgia Jet' and 'Jewel' roots harvested on 17 and 24 Oct. 1985, respectively. Roots of each cultivar were sorted for uniform size (4 to $6 \mathrm{~cm}$ diameter, 8 to $10 \mathrm{~cm}$ long) and placed randomly in lots of 10 roots for application of treatments. Mean weights of these lots of 10 roots were: 'Georgia Jet' $=1622 \pm 16 \mathrm{~g}$ and 'Jewel' $=1556 \pm 16$ g. All individual 10 -root lots were cured $(32 \pm 1 \mathrm{C}, 85 \% \pm$ $5 \% \mathrm{RH})$ for 7 days and then subjected to 0 , 4,8 , or 12 days of additional curing before being placed into storage $(16 \pm 1 \mathrm{C}, 85 \%$ $\pm 5 \% \mathrm{RH})$. Roots from each of the four extended curing treatments were presprouted $(32 \pm 1 \mathrm{C}, 85 \% \pm 5 \% \mathrm{RH})$ for $0,4,8$, or 12 days immediately before bedding on 14 Jan. 1986. After removing from presprouting, each lot was immersed for $15 \mathrm{sec}$ in a solution prepared with $640 \mathrm{~g}$ of $75 \%$ wettable powder 2,6-dichloro-4-nitroaniline (dicloran) in 40 liters water, air-dried, and then placed in $30 \times 40-\mathrm{cm}$ contiguous plots in a ground bed in a greenhouse. All plots were covered with $5 \mathrm{~cm}$ of fumigated Tifton loamy sand (fine-loamy, siliceous, thermic Plinthic Paleudults) and watered immediately after bedding and thereafter when the bed surface was dry to a depth of $1 \mathrm{~cm}$ to ensure adequate moisture levels for plant production. Granular fertilizer (28.0N-12.3P-23.2K, $\mathrm{gm}^{-}{ }^{2}$ ) was applied to the bed surface after the first plant harvest and followed by $5 \mathrm{~mm}$ of water. The air minimum in the greenhouse was $24 \mathrm{C}$ and the soil was at $28 \pm 4 \mathrm{C}$. The date of initial plant harvest varied by 4 weeks, depending on the treatment combination. Plants $\leq 20 \mathrm{~cm}$ high were harvested weekly from individual plots for nine consecutive weeks during a 13-week period, beginning when the first plant in a plot was $20 \mathrm{~cm}$ above the bed surface. Data presented are the cumulative number of plants harvested per plot after each plot was harvested at least once during the first five harvests (early plants) and the total number of plants harvested. Plants were weighed and counted after each harvest. After the ninth plant harvest from individual plots, roots were removed from the bed and counts were made for the remaining number of sprouts $>2 \mathrm{~mm}$ and the number of deteriorated roots. The entire root was classified as deteriorated if more than half was decayed.

The design was a randomized complete block with four replications of cultivar, extended curing, and presprouting in a $2 \times 4$ $\times 4$ factorial. Count data for number of days from bedding to first plant emergence, number of plants,. and number of sprouts were subjected to an $\mathrm{x}^{1 / 2}$ transformation. Data for plant weight were not transformed. Negligible deterioration of roots precluded analysis. Data were tested by analysis of variance. All transformed means were back-transformed for presentation.

'Georgia Jet' plants tended to emerge earlier than 'Jewel', and brief extensions of curing reduced the time until emergence of 'Georgia Jet' but not of 'Jewel' (Table 1). Lack of significant interaction of presprouting with cultivar or extended curing indicates that the influence of presprouting acted in an additive way in reducing the time until emergence of both cultivars, regardless of the in-

Where differences were significant, 'Georgia Jet' produced more early plants than 'Jewel' (Table 1). However, 'Jewel' produced more total plants than 'Georgia Jet', except with 12 additional days of curing; where the reverse was obtained. There was a significant quadratic increase in the number of early 'Georgia Jet', but not 'Jewel', plants with increased duration of curing. For unexplained reasons, early plant production was considerably lower in two of the four replications of 'Georgia Jet' subjected to 8 days of extended curing and 8 days of presprouting. This variation was reflected in a fluence of extended curing. significant cubic response of extended curing on total plant production for this cultivar. Other workers reported cultivar differences in plant production from sweetpotato roots cured for 10 or 15 days compared with roots cured for 5 days and then placed in conventional storage until bedding (Edmond, 1971).

The present results (Table 2) and other reports (Hall, 1987, 1990) show that short durations of presprouting increased the number of early and total plants harvested. Lack of interaction between presprouting and the main effects of cultivar or extended curing indicated that presprouting increased the number of early and total plants produced from roots of both cultivars, irrespective of the effect of extended curing on plant production. Both short extensions of curing and presprouting may be beneficial for increasing the number of plants produced from bedded roots of some sweetpotato cultivars, as demonstrated by 'Georgia Jet' in this study. Plant production of other cultivars may be responsive to brief presprouting but not to short extensions of the curing period, as demonstrated by 'Jewel'.

The average weight of early 'Jewel' plants was significantly higher $(20 \mathrm{~g})$ than that of early 'Georgia Jet' plants (16 g), and the average total weight of 'Jewel' (20 g) was significantly higher than that of total 'Georgia Jet' plants (17 g). Neither extended curing nor presprouting influenced these weights (data not shown). There were more 'Jewel' than 'Georgia Jet' sprouts (33 vs. $22, P=$ $0.01)$ remaining when roots were removed from the propagation bed, but neither extended curing nor presprouting influenced this variable (data not shown). These differences by cultivar in the number of sprouts remaining when roots were removed from the propagation bed may be related to the greater number of early plants produced by 'Georgia Jet' than by 'Jewel'. This difference may also indicate greater capacity for continued production of plants from 'Jewel' than from 'Georgia Jet' if additional plant harvests were conducted.

In the present study, plant production from roots subjected to a standard 7-day curing period was compared with plant production from roots subjected to short-duration increases in this standard curing period. In earlier work, plant production was compared between uncured roots and roots subjected to various durations of curing (Deonier and Kushman, 1960; Edmond, 1971) or between harvest dates (Edmond et al., 1948). In contrast to previous researchers, I also included comparisons of brief presprouting and extended curing and their possible combined effects on plant production. The present findings and those reported by Edmond (1971) may explain observations by Edmond et al. (1948) that 'Porto Rico' roots harvested in early September produced $11 \%$ and $19 \%$ more plants than roots harvested $\approx 6$ and 10 weeks later, respectively. Although not suggested by Edmond et al. (1948), differences they observed may have been related to longer durations of storage for earlier- than for laterharvested roots in facilities where the tem- 
peratures were high enough to have influenced plant production similarly to extended curing.

Average daily temperatures are $\leq 10 \mathrm{C}$ for January and February, when most sweetpotatoes are presprouted for early bedding at Tifton, Ga. (U.S. Dept. of Agriculture, 1983). Average daily temperatures are relatively high during the early part of the harvest period in most areas where sweetpotatoes are grown commercially. These differences in average daily temperatures at harvest and during the time of presprouting indicate potentially lower energy costs associated with plant propagation of responsive cultivars if the duration of curing can be extended and the duration of presprouting can be reduced. Further refinements in techniques for using short extensions of curing alone or in combination with brief presprouting may avoid problems such as shrinkage and reduced storage life reported by Steinbauer and Kushman (1971) from longer durations of curing.

\section{Literature Cited}

Cordner, H.B., H. Thomson, and MS. Jayyoussi. 1966. Proximal dominance and plant production in bedded roots of sweet potato, Ipomoea batatas Lam. Proc. Amer. Soc. Hort. Sci. $88: 472-476$

Deonier, M.T. and L.J. Kushman. 1960. The effect of presprouting and type of bed on the early production of sweet potato plants. Proc. Amer. Soc. Hort. Sci. 75:557-560.

Edmond, J.B. 1971. Seedstock selection and plan production, p. 81-105. In: J.B. Edmond and G.R. Ammerman (eds.). Sweet potatoes:. Production, processing, marketing. AVI, Westport, Conn.
Edmond, J.B., O.B. Garrison, W.S. Anderson, and V.R. Boswell. 1948. Cooperative studies of sweetpotato-plant production. U.S. Dept. Agr. Circ. 787. Washington, D.C.

Hall, M.R. 1987. Short duration presprouting enhances sweet potato plant production. HortScience 22:314.

Hall, M.R. 1990. Short-duration presprouting, ethephon, and cutting increase plant production by sweetpotato roots. HortScience 25:403-404.

Michael, R. and P.G. Smith. 1952. Stimulation of sweet potato sprout production. Proc. Amer. Soc. Hort. Sci. 59:414-420.

Steinbauer, C.E. and L.J. Kushman. 1971. Curing and storage, p. 42-46. In: C.E. Steinbauer and L.J. Kushman (eds.). Sweetpotato culture and diseases. Agr. Hdbk. 388. Agr. Res. Serv., U.S. Dept. Agr., Washington, D.C.

U.S. Department of Agriculture. 1983. Temperature and precipitation. Soil survey of Tift County Georgia. U.S. Dept. Agr., Soil Conserv. Serv. p. 70. 